\title{
LiMITS ON THE OPERATION OF EXCLUSION CLAUSES
}

\author{
KRISH MAHARAJ*
}

This article discusses exclusion clauses and instances when a court should intervene to limit the operation of such clauses. The author argues that exclusion clauses which are used improperly have the potential to damage the nature of contract by undermining the transfer or creation of rights under the contract. More specifically, the author discusses that exclusion clauses may eliminate obligations owed under the contract or absolve one party from liability completely. The author further argues that exclusion clauses allow for the unilateral alteration of the allocation of risk under a contract. In discussing these issues, the author makes reference to Canadian case law, particularly the Supreme Court of Canada's views on appropriate limits on enforcement of exclusion clauses. In conclusion, the author considers the validity of public policy as a rationale to address the various problems created by exclusion causes.
Cet article porte sur les clauses d'exclusions et les circonstances où les tribunaux devraient intervenir pour limiter l'exécution de ces articles. L'auteur fait valoir que les clauses d'exclusion qui ne sont pas utilisées correctement peuvent causer un préjudice à la nature du contrat en réduisant le transfert ou la création de droits en vertu de ce contrat.L'auteur fait tout particulièrement valoir le fait que les clauses d'exclusion peuvent éliminer certaines obligations en vertu du contrat ou absoudre une partie entièrement de sa responsabilité. L'auteur fait aussi valoir que les clauses d'exclusion permettent l'altération unilatérale de la répartition du risque en vertu d'un contrat. Dans ce contexte, l'auteur fait référence à la jurisprudence canadienne, tout spécialement les opinions de la Cour suprême du Canada sur les limites indiquées de l'exécution des clauses d'exclusion. En conclusion, l'auteur examine la validité de l'ordre public comme moyen d'aborder les divers problèmes occasionnés par les clauses d'exclusion.

\section{TABLE OF CONTENTS}

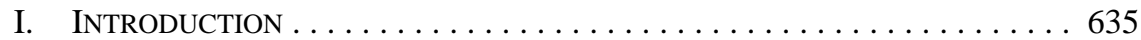

II. What is Contract AND Why Does It MATter? . . . . . . . . 636

III. INSTANCES IN WHICH EXCLUSION ClAUSES MAY

UNDERMINE THE FUNDAMENTAL NATURE OF CONTRACT . . . . . . . . 638

A. EXCLUSION ClaUSES MAY UNDERMine THE TRANSFER

OR CREATION OF RightS UndER THE CONTRACT . . . . . . . . 638

B. EXClusion Clauses May Permit the Unilateral

Alteration of THE AlLocation of Risk . . . . . . . . . . . 646

C. WHEN EXCLUSION ClaUSES REINFORCE A BARGAin

or Allocation of Risk that is Not FreE . . . . . . . . . . . 650

IV. The Most Recent Development: "Public Policy” . . . . . . . . 652

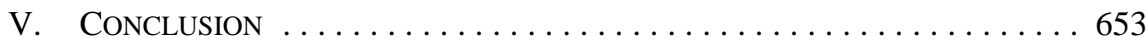

\section{INTRODUCTION}

Exclusion or exception clauses are a fact of not only modern contract law, they are a fact of life generally. They are to be found in contracts ranging from simple bailments to the most sophisticated technical and scientific endeavours. In the absence of an alternative they are simply indispensible. The potential cost of providing some of the most basic of services on a commercial scale would be grossly prohibitive without them. Yet among common

BCom/LLB (Auckland), LLM Candidate at UBC, Barrister and Solicitor of the High Court of New Zealand. The author is grateful to Professors Joost Blom and Bruce MacDougall for their thoughtful comments and assistance with this article. Any remaining errors or omissions are those of the author. 
commercial terms, they are among those subject to the most scrutiny and opprobrium. It seems plain that they cannot be done away with wholesale, but likewise, it does not appear that they can be allowed to operate unfettered in every situation. The question then is when should a court intervene to limit the operation of such a clause, and what is the rule or principle they should use in reaching that conclusion?

No answer is abundantly clear and a number of judicial formulations have been tried, tested, and rejected to date without any real sign of progress. I think, however, that a number of different instances of judicial intervention, as well as the theoretical objections that can be raised to exclusion clauses in extreme cases, can be reconciled with a single principal objection. In essence, it is that when exclusion clauses are used or relied upon improperly, they have the potential to undermine the fundamental nature of "contract." I regard this as a theme already present in the case law, and think it frames the need for limits on the operation of exclusion clauses in a fashion that is consistent with contract's institutional function and the law's own internal logic.

What I hope to achieve in this article is first, to explain how exclusion clauses can at times undermine the nature of contract in a legal or a practical/functional sense. Second, I hope to demonstrate, with reference to the particular objections discussed, an existing trend (alluded to above) of courts already acting to limit the operation of exclusion clauses in such circumstances. Both of these will hopefully allow me to build to a conclusion that the use of exclusion clauses in a manner that undermines the nature and correspondingly the function of contract is to some extent already precluded and that this frame of reference may be used to develop the law in this area in the future.

\section{What IS Contract AND WHY DOES IT MATTER?}

My analysis in this article is largely premised on a particular view of contract as an "institution." I believe that the most germane perspective on contract for the purpose of addressing the problem identified above, is of contract as a facilitative economic institution. ${ }^{1}$ This is not the only perspective that can be applied to analyzing contract law, but I argue that it is one whose logic has to some extent actually been internalized within contract law doctrine itself. ${ }^{2}$ I realize that this is a very broad proposition upon which many volumes have already been written and upon which I cannot make sustained critique or comment in a paper of this brevity. However, my critique in this article will adopt this premise as a starting point

See Henry Sidgwick, The Elements of Politics, 2d ed (London, UK: Macmillan and Co, 1897) at 82. In this work, Sidgwick, an influential nineteenth century political economist and moral philosopher, espoused the following view of contract that accords with this economic perspective:

In a summary view of the civil order of society, as constituted in accordance with the individualistic ideal, performance of contract presents itself as the chief positive element, protection of life and property being the chief negative element. Withdraw contract - suppose that no one can count upon the fulfillment of any engagement - and the members of a human community are atoms that cannot effectively combine; the complex co-operation and division of employments that are the essential characteristics of modern industry cannot be introduced among such beings (ibid at 82 [emphasis in original]).

See PS Atiyah, The Rise and Fall of Freedom of Contract (Oxford, UK: Oxford University Press, 1979) at 292-304, 359-83 (includes an expansive historical treatment of the history and development of contract law doctrine and the influence of the laissez-faire principle and political economy generally in the nineteenth century). 
and hopefully reinforce the notion that this perspective is the most useful for identifying underlying problems within the institution.

Economic orthodoxy today has it that the efficiency of a transaction is to be measured by the value of the surplus it generates (that is, the benefits it creates over and above the cost of the transaction) relative to its costs. ${ }^{3}$ It further posits that market transactions by definition generate greater surpluses than non-market or enforced transactions, such as theft or involuntary redistributions of property, or in effect the rights in said property. ${ }^{4}$ That surplus though is not a purely private benefit because it is not consumed by the parties to the transaction in its entirety. Instead, it is thought to convey a positive benefit at least in part on the rest of society. ${ }^{5}$

The means by which such transactions are achieved and thus surpluses are realized in most developed economies is by way of contract. This ability of contract to promote the greater good represents, I think, the underlying benefit or raison d'être of the institution, which I think correspondingly gives rise to the institution's legitimacy. Explicit judicial references to this public good arising from mercantile activity suggest an awareness of this aspect of contract and began to appear, as some authors suggest, not long (in the grand scheme of things) after such ideas began to permeate the popular and academic culture of the educated English elite. ${ }^{6}$ An example of this from 1874 may be when Sir George Jessel MR said in Printing and Numerical Registering Company v Sampson:

[I]f there is one thing which more than another public policy requires it is that men of full age and competent understanding shall have the utmost liberty of contracting, and that their contracts when entered into freely and voluntarily shall be held sacred and shall be enforced by Courts of justice. ${ }^{7}$

As such I would suggest that the nature of contract has been influenced by liberal economic concepts, or perhaps rather their progenitors or protoliberal economic ideas, and that contract law has developed in a fashion that reflects them. If I am correct, then as alluded to above, this conclusion has some potentially significant jurisprudential legal implications as well. It would appear to be a fact of life that not all bargains end well, and for one or more parties the consequences can be seemingly very harsh or even contrary to our ordinary perceptions of fairness. However, as Sir Jessel alludes to, the public interest requires that contracts be enforced and enforceable. In other words, the utility of "contract" on the whole provides the background moral justification for its existence as an institution and thus the potentially harsh outcomes created by rules necessary to protect the function of that institution. $^{8}$

RH Coase, "The Problem of Social Cost" (1960) 3 JL \& Econ 1 at 15; Richard A Posner, "Utilitarianism, Economics, and Legal Theory” (1979) 8:1 J Legal Stud 103 at 120.

Posner, ibid at 121.

Ibid at 123.

Atiyah, supra note 2 at 293.

(1875), 19 LR Eq 462 at 465.

See David Luban, Lawyers and Justice: An Ethical Study (Princeton: Princeton University Press, 1988) at 56 (includes an exposition of this concept which has been called the "institutional excuse"). 
Thus, a factor which undermines the fundamental nature of contract, as I believe exclusion clauses are apt to do, undermines both the utility of the institution as a whole and its legitimacy as a source of legal obligation.

\section{INSTANCES IN WHICH EXCLUSION CLAUSES MAY UNDERMINE THE FUNDAMENTAL NATURE OF CONTRACT}

\section{A. EXClusion Clauses MAY UNDERMine THE TRANSFER OR CREATION OF RigHTS UNDER THE CONTRACT}

As noted above, contracts are the normal means by which parties are able to transfer valuable rights to one another. From the orthodox economic perspective, this is the most important function of contract as an institution. As has been said, the transfer of these rights in a free market transaction is said to create a net surplus for both parties. There are two ways in which this may occur. First, the right may simply have an intrinsic value to the "acquirer" greater than its cost to him of acquiring. Second, ownership of that right may enable the acquirer to generate a surplus by exploiting that right to realize a pecuniary advantage. ${ }^{9}$ In order for either to work, however, the right must be effectively created in, or transferred to, the acquirer.

Exclusion clauses have an effect on this process of transfer or creation by effectively limiting or curtailing the right(s) that might otherwise be created in the acquirer. It is important to point out that the act of eliminating certain obligations is not inherently repugnant to the nature or function of contract. Contract only works in the manner envisioned by the economists when the cost of the transaction to the relevant party is lower than the benefit they receive. If the potential cost of assigning a particular right or undertaking a particular obligation is too high relative to the contract price, it would be counterproductive for that party to do so. As such, in some circumstances it does make sense for a party to eliminate certain obligations. That being said, if this process goes too far it would render the contract nugatory. If no rights are conferred or there is an insufficient collection of rights, the “purchaser” will be unable to create or realize a surplus. In my opinion, this objection ought to form a significant limit on the ambit of exclusion clauses and should be borne in mind during the exposition of contract law's theoretical treatment of exclusion clauses in the following section.

\section{DOCTRINAL PERSPECTIVES ON EXCLUSION ClAUSES}

Contract law's own internal perspective on the operation of exclusion clauses plays a significant role by at times allowing such clauses to undermine the nature and function of contracts. As such, to explain how this may occur, I will examine contract law's perspective on exclusion clauses and its potential consequences.

The doctrinal contract law perspective on exclusion clauses is that they eliminate liability for certain breaches of contract. There is no universal agreement as to how exclusion clauses achieve this and the type of rights they affect. However, there are two main competing 
theories that seek to explain how this works. ${ }^{10}$ It is worth noting that these theories use the vocabulary of "obligations" as opposed to rights, but in essence, one is the corollary of the other. If the concept of a "right" is capable of definition, it is most often thought of as a moral claim on others to respect certain interests, the concept of a moral claim being synonymous with the idea of an obligation to respect that interest. ${ }^{11}$

Orthodox contract law doctrine states that broadly speaking a contract has two types of obligations. These can be categorized as primary obligations and secondary obligations. ${ }^{12}$ Primary obligations are literally those things which a contracting party has either undertaken to do or refrain from doing. Secondary obligations are those that require a contracting party to pay damages for failing to perform their primary obligations. ${ }^{13}$ Secondary obligations are said to arise when the primary obligation has been breached and reflect the content and scope of the primary obligation they relate to. ${ }^{14}$ One point of difference between the two is that primary obligations generally arise from the mutual agreement of the parties, whereas secondary obligations are generally implied by law, but are open to modification by the parties. $^{15}$

The first theory, which may be described as "orthodox," focuses on the secondary obligations attaching to particular primary obligations, and the second, known as the "Coote/Diplock hypothesis," focuses on the relevant primary obligation itself. ${ }^{16}$ Both of which have particular consequences for the efficacy of contracts in their aforementioned role.

\section{a. Orthodox Theory}

As noted above, it is generally thought that a secondary obligation to pay damages implied by law may be modified by the parties in their contract. ${ }^{17}$ The original view, which I will refer to as the "orthodox theory" of exclusion clauses, effectively posits that to eliminate liability for the breach of a primary obligation, exclusion clauses eliminate the secondary obligation to pay damages that would have otherwise attached to the primary obligation. ${ }^{18}$

This approach theoretically reconciles the existence of the contract with the relevant party's inability to enforce certain parts of it because the relevant primary obligation still

Michael Furmston, Cheshire, Fifoot \& Furmston's Law of Contract, 15th ed (Oxford, UK: Oxford University Press, 2007) at 202-203.

11 See The New Shorter Oxford English Dictionary, 4th ed, sub verbo "right" (fifth definition "a legal, equitable, moral claim or title or claim to the possession of property or authority, the enjoyment of privileges or immunities etc.”).

$12 \quad$ RV Ward Ltd v Bignall, [1967] 1 QB 534 at 548 (CA (Eng)) [RV Ward]; Photo Production Ltd v Securicor Transport Ltd, [1980] AC 827 at 845, 848 (HL (Eng)) [Photo Production]; Moschi v LEP Air Services Ltd (1972), [1973] AC 331 at 350 (HL (Eng)) [LEP Air Services]; Brian Coote, Exception Clauses: Some Aspects of the Law Relating to Exception Clauses in Contracts for the Carriage, Bailment and Sale of Goods (London, UK: Sweet \& Maxwell, 1964) at 3.

13 John D McCamus, The Law of Contracts (Toronto: Irwin Law, 2005) at 761; GHL Fridman, The Law of Contract in Canada, 5th ed (Toronto: Carswell, 2006) at 512.

Photo Production, supra note 12 at 848.

Ibid at 849-50.

MH Ogilvie, “The Reception of Photo Production Ltdv. Securicor Transport Ltd in Canada: Nec Tamen Consumebatur" (1982) 27:3 McGill LJ 424 at 433; Furmston, supra note 10 at 202-203 (this is explained in somewhat different terms but effectively reflects the same idea).

Photo Production, supra note 12 at 848-49.

See especially Coote, supra note 12 at 2-3. See also Karsales (Harrow) Ltd v Wallis, [1956] 1 WLR 936 at 940 (CA (Eng)), Denning LJ [Karsales (Harrow)]. 
exists despite, as I will explain, being unenforceable. ${ }^{19}$ Taken to its logical conclusion it could be said that under this theory, no matter how broad an exclusion clause is, the party relying on it still provides consideration in respect of the contract in the form of the primary undertaking. In some cases, the relevant exclusion clause has appeared to almost go this far. ${ }^{20}$

\section{i. Effect on Enforceability}

To be clear from the outset, I think the suggestion that a primary obligation can exist without its concurrent secondary obligation is a work of fiction. As I noted above, I think that the inability to sue for damages in respect of the breach of a primary obligation effectively renders the primary obligation non-existent. This might not seem immediately obvious but should become clear if we consider that primary obligations are themselves unenforceable at common law. As such, the ordinary means by which such obligations are given content at common law is by way of an award of damages. Thus, I would think it apt to say that while separate, the two obligations are intertwined. Furthermore, I would even go so far as to say that it is the secondary obligation which defines the scope of the primary obligation, particularly in respect of provisions which are commercially notorious because specifying the extent of the award allows the court to indicate the extent of the obligation.

A critic might respond that I am overstating the importance of secondary obligations for two reasons. The first is the availability of specific performance or injunctive relief which can render primary obligations enforceable. I would respond that those are examples of infrequently granted discretionary remedies provided by Equity, and as such, depend on substantially different concerns than the enforcement of rights at common law. If anything, those remedies should be the exception which proves the rule, given that they are infrequently granted, and highlight the fact that primary obligations are otherwise unenforceable at common law as of right. As such, if a party has no ordinary entitlement to enforcement of a primary obligation, and cannot enforce the concurrent secondary obligation, it is in effect entitled to nothing.

The second reason is that a party entitled to remuneration is able to sue for the "contract price.” This example is cited by the learned authors of Chitty on Contracts who take the view that primary obligations are at times enforceable at common law. ${ }^{21}$ If this is the only example of direct enforcement of a primary obligation (and it is in fact the only one they cite), then support for the argument appears quite thin. ${ }^{22}$ The enforcement of the contract price is in theory said to be an example of the enforcement of the primary obligation literally to pay, but such an award is equally amenable to being recharacterized as damages quantified according to the relevant party's expectation under the contract. Characterizing it as the enforcement of a primary obligation may eliminate the defendant's ability to contest liability for lack of mitigation, but otherwise, it does not seem particularly far removed from a common law court's ordinary jurisdiction to award damages. Certainly the act compelled is

Coote, ibid; Ogilvie, supra note 16 at 433.

See e.g. Darlington Futures Limited v Delco Australia Proprietary Limited (1986), 161 CLR 500 (HCA) [Darlington Futures].

HG Beale, ed, Chitty on Contracts: Volume 1 General Principles, 29th ed (London, UK: Sweet \& Maxwell, 2004) at 15.

Ibid. 
no different, and I do not see how it can be used to argue that a common law court may compel a party to do, or refrain from doing, anything more than make reparation in kind.

If I am correct on the above analysis, then the elimination of concurrent secondary obligations under the orthodox theory begins to have significant consequences for the character of the "contract," both from an internal legal perspective as well as an external economic perspective. ${ }^{23}$

There are broadly speaking two, sometimes three, doctrinal definitions of the nature of a contract. The first regards contract as a legally binding form of "agreement," the second regards contracts as legally binding "promises" made reciprocally, and the third regards contract in terms of a "bargain." ${ }^{24}$ For the purposes of this discussion, I will adopt the term promise, but for my purposes the differing connotations of these two words are unimportant. What I wish to emphasize is the legally binding character. At common law, contracts are the only promises which have legal consequences, and this separates them from gratuitous promises, or mere promises, to which the common law does not give any legal effect. ${ }^{25}$ The corollary of this is that a promise without any legal consequence does not look like a contract even though it may theoretically comply with the requirements of form necessary to be enforceable, that is, retain some theoretical element of consideration. The economic perspective outlined at the outset of the paper reflects the doctrinal perspective outlined above, or vice versa, and is likewise compromised if obligations or rights conveyed in theory by the contract are not actually transferred in substance. A contract being made totally legally one-sided by an exclusion clause, however, is generally not acceptable to a court faced with that prospect. ${ }^{26}$ So the complete absolution of one party from all liability is not realistically a problem even though under this theory it could be possible. The real problem, which I hope will become more apparent after the discussion of the Coote/Diplock hypothesis, is that the internal contract law perspective may impose too high a threshold for intervention and does not appreciate the difference between the literal and the practical creation of a right.

\section{b. Coote/Diplock Hypothesis}

The alternative theoretical account of the operation of exclusion clauses, referred to above as the "Coote/Diplock hypothesis," was to my knowledge first proposed by my countryman Brian Coote in his 1964 monograph entitled: "Exception Clauses: Some Aspects of the Law Relating to Exception Clauses in Contracts for the Carriage, Bailment and Sale of Goods.”27

$23 \quad$ See especially Firestone Tyre \& Rubber Co, Ltd v Vokins \& Co, Ltd (1950), [1951] 1 Lloyd's Rep 32 at 39 (KB (Eng)) as per Devlin J (as he then was):

The position then would be that the lightermen have said: "We will deliver your goods; we promise to deliver your goods at such and such a place, and in the condition in which we receive them; but we are not liable if they are lost or damaged from any cause whatsoever.” That is not in law a contract at all. It is illusory to say: "We promise to do a thing, but we are not liable if we do not do it." If the matter rested there, there would be nothing in the contract.

Beale, supra note 21 at 3-4; Fridman, supra note 13 at 3-7.

Beale, ibid at 4. See Waltons Stores (Interstate) Limited v Maher (1988), 164 CLR 387 [Waltons Stores], which stated that unless or until Jorden $v$ Money, [1854] 5 HL Cas 185 (in which it was held that representations as to future conduct could not be relied upon as the basis for founding a common law estoppel) is repealed, the common law will not be able to give effect to purely gratuitous promises (ibid at 399).

26 AG Guest, ed, Benjamin's Sale of Goods, 7th ed (London, UK: Sweet \& Maxwell, 2006) at 13-031. Coote, supra note 12. 
It was this theory, which I will expound in greater detail below, that was subsequently adopted (without attribution) by Lord Diplock in his speech in Photo Production, thus leading to its partial attribution to his lordship. ${ }^{28}$

The theory states, as I understand it, that an exclusion clause does not eliminate the secondary obligation attaching to a primary obligation in order to negate liability for breach of that primary obligation. Instead, the exclusion clause eliminates the primary obligation itself, which has very different consequences. ${ }^{29}$ For instance, consider the following: under the orthodox theory an exclusion clause excluding liability for negligence would leave the obligation to observe a duty of care intact but prevent the relevant party from being responsible for breaching the obligation. Thus, even though the delinquent party has broken the contract, they are not liable for doing so. Under the Coote/Diplock hypothesis the exclusion clause actually eliminates the obligation to observe a duty of care. ${ }^{30}$ As such, the delinquent party is not liable for their failure to observe a duty of care because they were not actually obligated to do so, meaning they have not actually broken the contract. ${ }^{31}$

Of the two potential theories, this is the one I would prefer. Among other things, I think it is cleaner and simpler than the orthodox approach as well as more intellectually honest. Put simply, I think it makes much more sense to say that the party relying on the exclusion clause simply did not have the obligation alleged than it is to say they did have that obligation, but they are not responsible for violating it. As I will discuss below, this approach is not perfect either, but it does at least avoid the absurdity of insisting that unenforceable promises retain some value.

\section{ii. Why Might the Internal Contract Law Perspective Allow Exclusion Clauses to Undermine the Legal Character of Contracts?}

As noted above, the Coote/Diplock hypothesis avoids the problematic conclusion that unenforceable promises still have legal significance at common law. Concluding that an unenforceable promise does not exist is to my mind far more sensible and pragmatic. However, this theory is also problematic at times and may lead common lawyers to object to particular outcomes.

In John Weir's review of Coote's book in the Cambridge Law Journal, Weir points out that the theory propounded above works very well in the context of obligations implied by law, such as a duty of reasonable skill and care. ${ }^{32}$ Precluding the existence of an implied obligation does not immediately seem objectionable because it is not inconsistent with the

See Photo Production, supra note 12 at 850 per Lord Diplock. Note that his lordship makes no reference therein to Coote's work:

My Lords, an exclusion clause is one which excludes or modifies an obligation, whether primary, general secondary or anticipatory secondary, that would otherwise arise under the contract by implication of law. Parties are free to agree to whatever exclusion or modification of all types of obligations as they please within the limits that the agreement must retain the legal characteristics of a contract.

Coote, supra note 12 at 7-8.

Ibid at 7; Ogilvie, supra note 16 at 432.

Coote, ibid.

JA Weir, Book Review of Exception Clauses: Some Aspects of the Law Relating to Exception Clauses in Contracts for the Carriage, Bailment and Sale of Goods by Brian Coote, (1965) 23:2 Cambridge LJ 301 at 301-302. 
contract itself. It can be inferred that if the parties did intend for the obligation to exist they would have explicitly referred to it. That is not necessarily true, but it is the type of legal fiction which common lawyers readily accept. The difficulty that Coote himself identifies, and which is noted by Weir, is reconciling the operation of an exclusion clause in respect of explicitly assumed obligations. As Weir so ably puts it, the problem may be described as the “'appearance of duplicity' — when the small print takes away what the large had appeared to give.”33

This inconsistency alluded to above might be thought to create a prima facie difficulty in interpretation, but it appears that exclusion clauses are thought to limit the scope of the relevant obligation so the latter can simply be read down as required. ${ }^{34}$ So, it would appear that a party relying on an exclusion clause under this theory is allowed to give with the right and take with the left. A more ardent proponent of the theory might argue that to the extent such an outcome seems unfair, because it deprives a party of what they thought they had, it is merely a case of unilateral mistake. Such mistakes are not generally legally significant, unless one party knowingly takes advantage of the other's error, and thus should not otherwise be a cognizable basis to object to the ordinary operation of the contract. ${ }^{35}$ As with the orthodox theory though, it is not the legal analysis that may prompt us to object, but instead, the practical effect of the clause which may undermine the contractual character of the promise. ${ }^{36}$

\section{SigNiFICANCE OF DOCTRINAL PERSPECTIVES FOR CONTRACT'S ECONOMIC FUNCTION}

As hopefully illustrated above, the doctrinal legal theory of exclusion clauses may be apt to significantly undermine the fundamental nature of contract in some circumstances. The orthodox theory taken to the extreme for instance could eliminate all legal consequences for one party to a contract. If this were proposed as a basis to object to exclusion clauses, however, it would be something of a "straw man" since, as noted above, a court is highly unlikely to tolerate such an outcome irrespective of the theory. The Coote/Diplock hypothesis, by contrast, is not capable of rendering such an extreme result at all according to its own terms and requires that whatever obligations remain after the parties have modified them "must retain the legal characteristics of a contract." 37

$33 \quad$ Ibid at 302.

34 See especially Hawkes Bay \& East Coast Aero Club v McLeod, [1972] NZLR 289 (CA) (to do so would be to construct the contract ut res magis valeat quam pereat, or "that the deed have some meaning rather than be destroyed" as per Turner J).

35 See SM Waddams, The Law of Contracts, 6th ed (Aurora, ON: Canada Law Book, 2010) at paras 43637.

$36 \quad$ See Waltons Stores, supra note 25. See also Amalgamated Investment \& Property Co Ltd (in Liquidation) v Texas Commerce International BankLtd (1981), [1982] 1 QB 84 at 122 (CA (Eng)). Both of these cases indicate that in a widening array of circumstances, mistakes which are not strictly speaking relevant at law are instead providing a basis upon which an estoppel may be founded in equity, especially given that the factual restrictions of the traditional categories of estoppel appear to be vanishing. Now it seems that an estoppel could be founded in any circumstance where the adoption of the mistake was in some way referable to the behaviour of the party sought to be estopped, and their denial would be unconscionable in the circumstances. 
This approach, however, sets the threshold for the "contract" at a de minimis level of bare enforceability. It effectively means that a single enforceable promise, either secondary or primary depending on which theory you subscribe to, is apt to legitimate an entire contract. ${ }^{38}$ Viewed in light of the doctrine of consideration, this may seem to be an understandable conclusion to reach, as the law ostensibly makes no inquiry into the sufficiency of consideration. $^{39}$ The problem, however, is that the requirements of legal efficacy and economic efficacy are in this case quite different, for the reason that bare enforceability of the literal content of an obligation may be insufficient to create or transfer a right that is effective for its intended purpose. Nowhere would this be more apparent than circumstances in which a contracting party intentionally behaves in a manner inconsistent with its obligation(s), and is protected by an exclusion clause which precludes the existence of any obligation to the contrary.

Lord Wilberforce stated in Suisse Atlantique Société d'Armement Maritime SA v NV Rotterdamsche Kolen Centrale that there is no special rule to prevent an exclusion clause from excluding liability for intentional acts by a contracting party that undermine the rights of the opposite contracting party. ${ }^{40}$ If this is right, then the correct approach would appear to be simply construing the clause in light of the surrounding circumstances and the apparent intentions of the parties in order to determine if the clause was meant to cover such an intentional breach. ${ }^{41}$ However, the reality of enforcement appears to be somewhat different in many cases.

The experience in practice appears to have been that courts are at times unwilling to allow a party to unmeritoriously rely on an exclusion, or analogous clause, in order to assimilate or undo the other parties' benefit under the contract. Two prominent decisions of this nature are Chomedy Aluminium Co Ltd v Belcourt Construction (Ottawa) Ltd and Tor Line AB v Alltrans Group of Canada $L t d .{ }^{42}$ In both cases, the sharp dealing of the party seeking to rely on the "exclusionary clause" effectively prompted the Courts to disentitle them from relying on the exclusion, in spite of their actions prima facie falling within the scope of the relevant clause.

In Belcourt Construction, Justice Wilson (as she then was) stated that the property developer could not rely on a subcontractor's waiver of a statutory lien as a means of disclaiming their obligations. ${ }^{43}$ This, however, is in spite of the fact that the waiver of lien must have been intended to prevent the subcontractor from asserting such a lien in the context of any dispute over payment. Any supposition in the circumstances then that the operation of the waiver was intended to be contingent on the dispute being meritorious seems to be judicial sleight of hand, for the reason that the waiver would be inherently uncertain and unenforceable if such a qualification were to be implied. Instead, it would seem that the Court simply did not wish to allow the developer to render the benefits of the subcontractor's bargain nugatory.

See Guest, supra note 26 at 13-031.

See Guenter Treitel, The Law of Contract, 11th ed (London, UK: Sweet \& Maxwell, 2003) at 73-74. (1966), [1967] 1 AC 361 at 435 (HL (Eng)) [Suisse Atlantique].

Beale, supra note 21 at 795-96.

(1979), 24 OR (2d) 1 (CA) [Belcourt Construction]; (1983), [1984] 1 WLR 48 (HL (Eng)) [Tor Line]. Belcourt Construction, ibid at 9. 
In Tor Line, the owner of a vessel could not rely on an exclusion clause to avoid liability for loss suffered by the charterer that resulted from the owner's provision of a vessel smaller than that specified in the charter. This is despite the fact that the clause in issue was sufficiently broad to embrace the act in question and not apparently susceptible to any other meaning. In accordance with the objection I have stated above, though, it was said by Lord Roskill that

\begin{abstract}
if [the exclusion clause] were to be construed so as to allow a breach of the warranties as to description in clause 26 to be committed or a failure to deliver the vessel at all to take place without financial redress to the charterers, the charter virtually ceases to be a contract for the letting of the vessel and the performance of services by the owners ... and becomes no more than a statement of intent by the owners in return for which the charterers are obliged to pay large sums by way of hire, [and]... are entitled to nothing in lieu. ${ }^{44}$
\end{abstract}

Lord Roskill in that case makes reference to the presumed intentions of the parties in concluding that such an outcome cannot be allowed, but I would think, in light of his clear opinion that such an outcome would undo the contract, that this is a throwaway comment at best. $^{45}$

On the other side of the judicial coin, proving that exclusion clauses can virtually render a contract non-existent for want of legal effect, is the High Court of Australia's decision in Darlington Futures. ${ }^{46}$ In this case the High Court disallowed reliance by an investment broker on an exclusion clause when he had intentionally breached his mandate and engaged in multiple unauthorized trades resulting in substantial losses. ${ }^{47}$ The clause itself specified it pertained to losses caused in the course of acting within the client's mandate, so this does not appear extraordinary. The Court did, however, allow the broker to rely on a limitation clause that restricted liability for any action connected with the provision of his services to $\$ 100$. The Court upheld this on the basis that the actions of the broker fell within the ambit of the clause. ${ }^{48}$ In the context of losses amounting to approximately AUD \$300,000, this could be no better than losing the action, except of course for the issue of costs. Whether a similar approach would have been taken if the exclusion clause itself had been worded so broadly is not realistically an issue given the Australian position that no sharp distinction between limitations and exclusions should be drawn. ${ }^{49}$ This outcome, to my mind, is astounding and begs the question of what level of absurdity would have to be reached before the court intervened? The unauthorized trading amounted effectively to a failure to render the services the client had requested whatsoever, and yet, this complete annihilation of the benefit of the client's bargain and the accompanying losses were permitted.

I believe that the result in the former two cases in contrast with Darlington Futures demonstrate that a concern to protect the economic as well as legal efficacy of contracts is already present in the common law. However, I think when the reasoning between the former two and Darlington Futures is compared, it is clear that a more clearly articulated guiding

Tor Line, supra note 42 at 58-59.

Ibid.

Supra note 20.

Ibid at 506-507.

Ibid at 511.

Ibid at 510 . 
principle for the control of exclusion clauses is needed if courts are to render consistent results and avoid sanctioning the destruction of bargains. Although all three cases ostensibly consider themselves to be interpreting and applying the contract in some sense consistent with Lord Wilberforce's view in Suisse Atlantique, it seems apparent to me that the former two are in effect evaluating the purported use of the clause against some external standard. That standard in my opinion is the effect of the purported use of the clause upon the legal and economic efficacy of the parties' agreement, which seems to be the most principled basis upon which to determine the applicability of such a clause.

\section{B. Exclusion Clauses May Permit the Unilateral Alteration of THE AlLOCATION OF RISK}

Apart from the allocation of rights and obligations, contracts perform a number of other important economic and commercial functions, an important example of which is acting as risk allocation mechanisms. This aspect of contract's persona is different in character and has a different focus from contract's primary function discussed in Part II. The allocation of rights and obligations discussed in that section is essential when the venture at the heart of the contract goes well. By contrast, the allocation of risk between the parties plays a fundamental role in determining who shall suffer the consequences of misadventure, and in what proportion. It is no less significant a component of contract however, and in an arm'slength transaction, all three should be interrelated with the mix of rights, obligations, and risks assumed reflecting each party's opinion as to what is in their best interests.

Of course, all decisions that require some knowledge of the future are something of a gamble, but if this economically orthodox scenario is correct, all who wager are equally free to act according to what they apprehend the future state of affairs will be. Assuming this to be true (and that we live in a perfect world), when the worst happens and some parties are forced to shoulder a loss greater than others, that cannot be said to be inherently unfair. A party who has freely made their bed must surely sleep in it.

The description offered above seems to be the implicit, occasionally explicitly recognized, attitude of the common law to the allocation of risk in contracts. ${ }^{50}$ There are, however, circumstances in which this model of the commercial world, and consequently support for the ordinary legal consequences of contracts, begin to break down. An example of this is when the transacting process leading to the allocation of risk is itself not equal, but this circumstance and its discussion will be dealt with under the heading of unconscionability below. The other occurs when the risk which gives rise to the loss was not in fact within the contemplation of the parties at the time of the contract, and is instead imposed by one party upon the other.

It would not ordinarily be considered unfair if a party were to suffer from loss arising from a contemplated risk, or perhaps even for loss arising from an uncontemplated risk that arose independently of any parties' actions. ${ }^{51}$ As such, there would appear to be little reason for a

Guest, supra note 26 at $13-004$.

Although to some extent this is remedied by frustration where the risk has rendered performance impossible. 
court to interfere and disturb the consequences of the parties' bargain. It would seem to be altogether qualitatively different, however, if a party were to suffer a loss arising from a risk unilaterally imposed upon them for no better reason than that they appear to be responsible for it under the terms of the contract. The difference between the two scenarios, I think, is that the latter outcome would undermine the process of generating a surplus for the party who has suffered the loss. This would not be because of the loss itself, but instead, because unilaterally imposed exposure to a risk that could deprive a party of their benefits under a contract has the effect of rendering those rights illusory if their opposite is not liable for the loss arising from the unilateral imposition of risk. By contrast, even uncompensated losses arising from risks genuinely accepted do not have this effect because any rights created or transferred by the contract must exist subject to that qualification, and as such, the rights conferred would not extend to a right to compensation in respect of losses arising from those risks.

\section{REFLECTION IN THE CASE LAW}

Arguably prior to the House of Lords' final rejection of the doctrine of fundamental breach in Photo Production, or "the rule of law" approach to fundamental breach as a mechanism to limit the operation of exclusion clauses, the law was that when a "fundamental breach" occurred it brought about the end of the contract and nullified any relevant exclusion clause. This left the innocent party free to sue for damages under the contract as if the exclusion clause had not existed. ${ }^{52}$ Fundamental breach was apt to encompass any breach that went to the root of the contract and could have potentially encompassed deviations from the agreed parameters of a contract that fundamentally changed the parties' allocation of risk or terms of their bargain.

Reasoning which centred around the adverse effect of a party's actions on risk allocation as a justification for disallowing the ordinary operation of an exclusion clause had already existed for some time in shipping law in the form of the doctrine of deviation. ${ }^{53}$ The rule encapsulated in that doctrine is that when a carrier deviates from the agreed course of the voyage, any limitation of liability in the bill of lading ceases to be effective. ${ }^{54}$ It is noteworthy that according to the shipping cases this is so even where the deviation did not cause the loss or damage suffered. ${ }^{55}$ However, the doctrine is said to be premised on the fact that the shipper's contract of marine insurance will be rendered void by the deviation, so it would appear that the doctrine is still referable to the parties' allocation of risk. This may seem somewhat more explicable when it is considered that the ordinary rule in shipping law is that the carrier is effectively an insurer of the goods, unless the contract of carriage or bill of lading specifies otherwise; as such, the carrier's deviation inhibits the shipper's ability to adequately bear the risk of loss in the carrier's place by invalidating their insurance arrangements. ${ }^{56}$ This somewhat more specific doctrine then presents, or perhaps presented,

\footnotetext{
52 Harbutt's “Plasticine” Ltd v Wayne Tank and Pump Co Ltd (1969), [1970] 1 QB 447 at 448 (CA (Eng)) [Harbutt's Plasticine].

Beale, supra note 21 at $812-13$.

Ibid.

Ibid.

Treitel, supra note 39 at 229.
} 
an avenue for the further development of fundamental breach to prevent exclusionary clauses undermining contract in the manner outlined above.

The rule of law approach to fundamental breach, however, was ostensibly eliminated by the House of Lords in Suisse Atlantique, although it was not until Photo Production when the House of Lords explicitly drew a line under the doctrine and overruled Harbutt's Plasticine (which attempted to resurrect the doctrine), that it could be said to have been discarded altogether. ${ }^{57}$ Harbutt's Plasticine, though, became significant in respect of the consequences of a party changing the agreed allocation of risk, not necessarily because of what it said, but because of its obvious inconsistency with Suisse Atlantique. That aforementioned inconsistency necessitated lower courts finding some way in which to reconcile the two, and in subsequent cases, it was said that Harbutt's Plasticine was justifiable and reconcilable with Suisse Atlantique on the basis of the doctrine of deviation. ${ }^{58}$ The suggestion that the doctrine of deviation was potentially applicable more broadly than maritime cases was not novel, having been made in Suisse Atlantique. ${ }^{59}$ However, this was undone when Lord Wilberforce resiled from his comments to that effect in Suisse Atlantique in his later speech in Photo Production, wherein he described the doctrine as sui generis. ${ }^{60}$

In effect, this should have had a somewhat stultifying effect on the application of this type of reasoning to impeaching the applicability of exclusionary clauses, not only in England, but in any jurisdiction in which Photo Production was adopted. As noted earlier, the reasoning in Photo Production was largely adopted in Canada by the Supreme Court in Hunter $v$ Syncrude.$^{61}$ However, as some authors have pointed out, even after this decision lower courts continued to apply covertly, and may still be applying, the rule of law approach. ${ }^{62}$ As such, the possibility has remained that courts may approach the possible impeachment of an exclusion clause in appropriate cases on the basis of the effect of the delinquent party's actions on the agreed allocation of risk.

An example of this being done resulting in judgment in favour of the plaintiff is Solway $v$ Davis Moving \& Storage Inc, in which two members of the Ontario Court of Appeal considered the allocation of risk agreed to in the terms of an agreement for storage of the plaintiffs' effects. ${ }^{63}$ The effects were meant to be stored in a shipping container in the defendant's yard overnight, but the container was instead left in a public street and subsequently stolen. Justice Labrosse for the majority seems to imply that the defendant's failure to store the goods in their yard violated their obligation to store the goods securely, which must have disentitled reliance by the defendant on the exclusion clause. ${ }^{64}$ The implication is that the defendant had changed the incidence of risk resulting in the theft. Justice Carthy by contrast explicitly considered risk allocation as a function of contract and took the view that the defendant's actions were a negligent mode of performance, not a

57

See Harbutt's Plasticine, supra note 52; Hunter Engineering Co v Syncrude Canada Ltd, [1989] 1 SCR 426 [Hunter v Syncrude] (the same reasoning as Photo Production was adopted by the Supreme Court of Canada in this case).

Kenyon, Son \& Craven Ltd v Baxter Hoare \& Co Ltd (1970), [1971] 1 WLR 519 (QB (Eng)).

Suisse Atlantique, supra note 40 at 434.

Photo Production, supra note 12 at 845.

Supra note 57.

Waddams, supra note 35 at para 479.

(2002), 62 OR (3d) 522 (CA) [Solway].

Ibid at paras 19-21. 
failure to perform their obligation to store the goods securely and should not disentitle reliance on the clause. ${ }^{65}$ Central to Justice Carthy's analysis, however, was the fact that storage in the street as opposed to the yard made very little difference as the yard was not patrolled nor alarmed, and no thefts had occurred in the past 30 years in any event. ${ }^{66}$ As such, the incidence of risk was not changed and did not in itself give rise to any loss.

Similar reasoning and analysis can also be found in the much earlier decision of the High Court of Australia in The Council of the City of Sydney $v$ West, which involved a vehicle being stolen from a Council owned public parking garage.$^{67}$ In that case, the theft was made possible by the employees of the Council when they failed to follow security measures routinely followed to ensure that persons leaving the garage with a vehicle were in fact the persons who had parked the car in the first place. The case, likewise, turned on whether those actions were a negligent mode of performance or a failure to perform. The significance of the distinction appears to be that where a positive obligation exists, a party failing to adhere to it may change the incidence of risk and impose a greater risk on the other party than they had agreed to. Negligent performance on the other hand may not change the incidence of risk in this way, if the clause excludes liability for negligent performance. As was pointed out by Chief Justice Barwick and Justice Taylor, there is a difference between negligent performance and negligent or intentional performance of a kind outside of the contemplation of the contract. Only in the latter case were they of the opinion that liability should flow, despite any ordinary exclusion of liability for negligence. ${ }^{68}$ The justification for which I think must implicitly be, as it seemed to be in Justice Carthy's judgment in Solway, that the risk which gave rise to the loss was not one that the other party had assumed.

The antipathy of the current authorities towards deviation is not factored into either decision discussed above; in the first case, it is likely through inadvertence, and in the latter, because it was decided in 1965. The significance of the decisions, though, is I think that they adopt reasoning centered on the allocation of risk and determine the significance of the defendant's breach of contract in light of that allocation to determine the defendant's ability to rely on the relevant exclusion clause. This I think has to be the corollary of courts justifying the operation of exclusion clauses in other cases on the apparent risk allocation made by the parties, as was done by Justice Robins for the Ontario Court of Appeal in Fraser Jewellers (1982) Ltd v Dominion Electric Protection Co and the House of Lords in Photo Production itself. ${ }^{69}$ Thus, I would disagree with their lordships in Photo Production that the doctrine of deviation is sui generis to shipping cases only, as the concept and reasoning appear to be more widely dispersed.

If I am correct about risk allocation as an important part of contract law's function and persona, then I think the foregoing conclusion is not surprising because this type of reasoning appears to have intrinsic appeal to contract law for two reasons. First, it protects the function of the institution by ensuring that the parties receive the rights that they are entitled to under the contract; that is, rights that are only qualified by other operation of law and the risks they

Ibid at paras 49-51.

Ibid at para 27.

(1965), 114 CLR 481 (HCA).

Ibid at 488-89.

(1997), 34 OR (3d) 1 at 12 (CA); Photo Production, supra note 12 at 846. 
have voluntarily assumed. Second, it protects contract law's integrity as a source of obligation by ensuring that the burden of loss is allocated in a fashion that is consistent with contract law's own internal logic, which in the ordinary course of things requires that any loss a party is made to shoulder must be one that that party has voluntarily agreed to assume. ${ }^{70}$ As such, I think these cases demonstrate a principle or frame of reference which may be usefully used to develop the law in relation to limits on the operation of exclusion clauses in a principled way, if more explicit attention is paid to the underlying rationale which can and should be more clearly articulated.

\section{WHEN EXCLUSION CLAUSES REINFORCE A BARGAIN OR Allocation OF Risk THAT IS Not FreE}

As explained above in the previous section, the orthodox economic model of contracts or the process of contracting breaks down at times in the real world which, in turn, inhibits the proper function of the institution. If we take the orthodox economic perspective that transactions are theoretically optimal when they are freely entered into, then any transaction which is not the product of a free bargaining process in which rights, obligations, and risks are traded quid pro quo, will not create the greatest surplus possible or, in other words, an economically efficient outcome. ${ }^{71}$

One of the circumstances in which this is apt to happen is when the bargaining process leading to a contract is influenced by an inequality of bargaining power that results in the stronger party imposing unfavourable terms upon the weaker. A not infrequent example of this type of behaviour is, unsurprisingly, very broad exclusion clauses.

Concern to prevent such outcomes is actually already well-reflected in law although it is perhaps not as well understood as might be hoped, and as such, the legal response to prevent such outcomes occurring is not as consistent as perhaps it should be.

\section{REFLECTION IN THE CASE LAW}

The equitable doctrine of unconscionability has for centuries, and at least since Waters $v$ Donnelly in Canada, protected weaker parties from overreaching by the strong. ${ }^{72}$ At the beginning of the nineteenth century, a court of Equity's jurisdiction to intervene under this head was said to be quite broad, as demonstrated by the words of Vice Chancellor Leach in Wood v Abrey: "a Court of Equity will inquire whether the parties really did meet on equal terms; and if it be found that the vendor was in distressed circumstances, and that advantage was taken of that distress, it will avoid the contract." ${ }^{\text {73 }}$ In subsequent decades of that century

See Tercon Contractors Ltd v British Columbia (Transportation and Highways), 2010 SCC 4, [2010] 1 SCR 69 [Tercon]. This type of concern is alluded to by Binnie J, dissenting, when he states that "[t]o enforce an exclusion clause in [circumstances of a harsh or unconscionable bargain] could tarnish the institutional integrity of the court" (at para 108, discussing the view of Dickson CJC in Hunter v Syncrude, supra note 57).

71 Belcourt Construction, supra note 42, Wilson JA (“[m]any exclusionary clauses (and I am now referring to clauses which are clear and unambiguous and require no construction) which in isolation seem unfair and unreasonable are not so when viewed in their contractual setting and may, indeed, constitute part of the quid pro quo for benefits received through hard negotiation” at 8 [emphasis added]).

72 (1884), [1885] 9 OR 391 (Ch).

(1818), 56 ER 558 at 560. 
and well into the twentieth century, however, a hardening of the law's attitudes in favour of individual freedom and cultivation of commercial certainty saw the law in this area contract from what was quite a broad proposition cited above to a comparatively more narrow one: " $[t]$ he result of the decisions is that where a purchase is made from a poor and ignorant man at a considerable undervalue, the vendor having no independent advice, a Court of Equity will set aside the transaction." ${ }^{\prime 74}$ The view of Justice Kay in Fry $v$ Lane expounded in the quotation above, which is of a much more limited scope than the earlier view of Vice Chancellor Leach in Wood v Abrey, appears to have remained the law's "official line" in relation to the possible scope for intervention to relieve a party from a seemingly "unfair" bargain. The reality of the fact, though, in the opinion of Stephen Waddams in The Law of Contracts, with whom I agree, is that there is a marked difference at times between that which the law says and that which the law does. As such, as that learned author further points out, it appears from the reported decision that courts in reality are prepared to intervene under this heading much more readily than the orthodox view would supposedly allow. ${ }^{75}$

The two views above, as I understand it, may be referred to as substantive unconscionability in the former case and procedural unconscionability in the latter. The former reflects a concern to prevent immoderate advantages from being obtained through any weakness in bargaining power that might exist in the circumstances, and the latter is concerned only with protecting those individuals, who for whatever reason, are inherently unable to properly guard their own interests. On the question then of whether Equity permits intervention in situations of procedural unconscionability only, or may intervene more broadly to prevent substantive unconscionability, I would prefer the latter view despite authoritative pronouncements to the contrary. ${ }^{76}$ If I am correct, then the doctrine would appear to be well-suited to addressing the particular problem alluded to in the introduction to Part III.C and would perhaps conform with other examples of equitable intervention to provide relief from particularly harsh or unfair contractual terms such as penalties and forfeitures.

The appropriate use of the doctrine in this fashion in relation to exclusions can I think be ascertained from the seminal decision of the House of Lords in Dunlop Pneumatic Tyre Company Limited $v$ New Garage and Motor Company Limited. ${ }^{77}$ In that case, their Lordships considered that the rule against penalties may have stemmed from unconscionability or Equity's antipathy towards unconscientious bargains. ${ }^{78}$ The significance of this, it was said, was that the term in question must have been "extravagant" or unfair in the circumstances of the agreement. ${ }^{79}$ The important conclusion is that a high liquidated damages clause is not in itself unconscionable, but instead, it is only unconscionable where it is not in fact referential to the substance of the bargain. I would think this must be equally true of contractual terms the doctrine is applied to generally, and if the law were to conform to the need to protect the integrity of the contracting process generally, it would seem more than appropriate to apply this approach to exclusion clauses.

$74 \quad$ Fry $v$ Lane (1888), 40 Ch D 312 at 322, Kay J (referring to the words of Lord Selbourne from Earl of Aylesford v Morris (1873), 8 Ch App 484 at 490).

Waddams, supra note 35 at para 443.

McCamus, supra note 13 at 406-407.

(1914), [1915] 1 AC 79 (HL (Eng)).

Ibid at 88 .

Ibid at 95. 
I am of the opinion that the doctrine's scope extends to all contractual terms that may have been the product of an unequal bargaining process, but it has assumed particular significance in relation to exclusion clauses. This stems from the comments of Justice Wilson and Chief Justice Dickson in Hunter v Syncrude, where Justice Wilson suggested it was a ground on which to strike down an exclusion clause and the only ground on which to do so by Chief Justice Dickson. ${ }^{80}$ As I will discuss, these comments have prompted a much more expansive Canadian treatment of the doctrine; however, even in its original sense, I still think it is a useful tool for addressing this particular problem.

Unfortunately, as was predicted by Justice Wilson in Hunter $v$ Syncrude, the use of the term unconscionability as the sole criterion for assessing the validity of an exclusion clause, as suggested by Chief Justice Dickson, has actually shifted the supposed application of the doctrine entirely outside of its traditional scope ${ }^{81}$ As has been mentioned earlier, even after Hunter $v$ Syncrude, Canadian courts continued to effectively apply the rule of law approach to fundamental breach. However, I think in an effort to make themselves consistent with authority, some courts have relied on the rubric of "unconscionability" as the supposed basis for their intervention. This becomes quite apparent when the use of the term is examined because it is clearly not being used in the traditional doctrinal sense expounded above.

A particularly prominent example of this form of judicial sleight of hand is the Alberta Court of Appeal's description of the defendant Dow Chemical of Canada Ltd's conduct in Plas-Tex Canada Ltd v Dow Chemical of Canada Limited as "unconscionable," when the description clearly bore no relationship to the terms of the contract itself. ${ }^{82}$ As discussed above, I believe this is better characterized as an example of a court stepping in to prevent an intentional breach that would undermine the rights of the innocent party, despite the rubric of unconscionability present in the reported case. As such I think that decisions of this nature, or pre-Hunter v Syncrude decisions such as Belcourt Construction, which used similar language, should be seen as changing the parameters of the doctrine. ${ }^{83}$ As will be discussed below, however, in light of Tercon, the need to rely on the rubric of unconscionability to justify all intervention may no longer exist, which may mean that the term can return to being used in what I have proposed above as its original doctrinal sense. ${ }^{84}$

\section{The Most Recent Development: "Public Policy"}

The most recent word (one could not realistically say last) on the appropriate limits to enforce on the operation of exclusion clauses comes from the recent Supreme Court of Canada decision in Tercon. In that case, the Court was divided as to the effect of the exclusion clause in question with the majority lead by Justice Cromwell holding that the clause by virtue of its wording did not apply, and Justice Binnie, dissenting, holding that it did apply. ${ }^{85}$ Despite the difference of opinion with respect to the clause, however, the

Hunter v Syncrude, supra note 57 at 516, 462.

Ibid at 516 .

2004 ABCA 309 at paras 54-55, 245 DLR (4th) 650 [Plas-Tex v Dow].

Belcourt Construction, supra note 42.

Tercon, supra note 70.

Ibid at paras 76, 86 . 
majority agreed with Justice Binnie’s approach to deciding whether an exclusion clause was effective in the circumstances. ${ }^{86}$

Justice Binnie opined that the court should go through a three-stage process. First, the court should determine as a matter of construction whether the clause applies at all. Second, the court should consider whether there was an inequality of bargaining power between the parties which made it unconscionable to enforce the clause. Third, the court should consider whether there is any paramount reason of public policy that should motivate the court to strike down the clause. ${ }^{87}$ This final consideration is rather novel and depending on what was meant, or rather what later courts take this to mean, it may be apt to address the various problems discussed above, as well as potentially supersede the other various judicial devices that have been previously employed to limit the operation of exclusion clauses in the past.

In discussing the relevant public concerns, Justice Binnie states that preventing the abuse of freedom of contract is a worthy policy concern in and of itself, and one that may provide grounds for a court to withhold its assistance from a delinquent party in particular circumstances. ${ }^{88}$ Support for this proposition is drawn significantly from Plas-Tex $v$ Dow, in the circumstances of which Justice Binnie states that "[t]he public policy that favours freedom of contract was outweighed by the public policy that seeks to curb its abuse." ${ }^{89}$ In the context of Justice Binnie's wider discussion, he may be referring to either competing public interests such as concern for public health and safety or means that the court should intervene when the public policy underpinning freedom of contract itself would be undermined by reliance upon the clause. These two are not entirely mutually inconsistent, however, and perhaps even if the latter is meant, it is possible that future courts will interpret Justice Binnie's obiter dicta as providing authority to intervene, as I have argued they should, when a party's conduct would undermine the public interest supporting freedom of contract. $^{90}$ If this is the approach taken, then I would think that the doctrine of unconscionability, which has been stretched from its previously understood dimensions to fill the void left by the abolition of fundamental breach, may no longer have to be employed in this way.

\section{CONCLUSION}

What I have tried to achieve in this article is to demonstrate that an economic perspective on contract is an apt way of viewing certain trends in the imposition of limits on exclusion clauses. I have argued that this perspective is in essence already internalized to some extent within contract law and represents some aspect of the underlying logic employed by the common law, and to some extent, Equity also. I have suggested this from a historical perspective and relied upon Patrick Atiyah's seminal work in The Rise and Fall of Freedom of Contract. This I think helps illustrate the influence of classical economic thought on the development of modern contract during its genesis. However, that would not necessarily be

Ibid at para 62.

Ibid at paras 122-23.

Ibid at para 119.

Ibid.

See Atiyah, supra note 2 at 123. Judges of antiquity, such as Lord Mansfield, arguably did before contract law entered its lengthy period of rigidity toward the late nineteenth century. 
sufficient to argue that economic analysis has had continuing relevance in the intervening centuries, especially after what Atiyah refers to as the "separation of the social sciences." The conclusion that I would draw from the examples of judicial intervention I have discussed, though, is that the argument in favour of economic reasoning already being present in the law can be supported by reverse inference from the decisions judges have reached, which seem to conform to certain underlying premises consistent with an economic perspective on the function of the law.

If I am correct, then this may signify that the protection of the character of contract as a facilitative economic institution is an appropriate guiding principle perhaps for judicial intervention generally, and a principle that is particularly germane to imposing limits on exclusion clauses for the reasons discussed. Whether it does so explicitly though, depends on whether the public policy approach advocated in Tercon opens the judicial mind to consider the underlying public policy or function of contract generally and its function as an institution. Either way, I think it is the case that whether consciously or not, intervention to limit the operation of exclusion clauses will continue to reflect the needs of contract as an economic institution well into the future, and only predictability and accuracy of decisions will be improved if the principle is brought into focus explicitly. 